\title{
The Poetics of Mythological Spaces in Contemporary Vietnamese Prose from 1986 to Present
}

Quoc Hieu Le, M.A, Institute of Literature (IoL), Vietnam Academy of Social Sciences (VASS), 20 Ly Thai To, Hoan Kiem, Hanoi. Email: hieulequoc@gmail.com

\begin{abstract}
Myth and mythological criticism have become a significant concern for literary studies. Mythological materials and thinking have been penetrated and regenerated in contemporary literary writings, forming unique creative writing against socialist realism aesthetics. The article explores some specific poetics of mythological spaces in Vietnamese narratives since 1986 . Through the analysis of spatial aesthetics in some works written by Pham Thi Hoai, Nguyen Huy Thiep, Ta Duy Anh, Chau Dien, and Nguyen Xuan Khanh, the article points out the distinctions of mythological spaces, including the binary spaces, the spiritual and legendary spaces, and the symbolic spaces.
\end{abstract}

Keywords: Mythological Criticism; Spatial Poetics; Contemporary Vietnamese Prose, Mystification

\section{INTRODUCTION}

Recently, myth and mythological criticism have become a significant concern in literary studies. Mythological materials and thinking have been penetrated and regenerated in literary writings, forming unique creative writing against socialist realism aesthetics, which dominated Northern Vietnamese culture and arts from 1945 to 1975. The aesthetic patterns (spatial and temporal forms, characters, archetypes, symbols, and motifs) originating from the ancient myths or monomyths are constantly being moulded, revitalised, and interacted in contemporary literary texts (Le, 2017, p. 42).

Chronotope (literally, time-space) is one of the aesthetic dimensions of artistic images. Chronotope "is used in poetics by M.M. Bakhtin to refer correlational and interdependent relationship between spatial and temporal images and the characteristics of the characters in works" (Tamarchenko, 2015). Bakhtin raised the importance of choronotope to grasp different 
aspects of time and space used in the current stage of humankind to find ways to realise the faces of reality. In Vietnam, from 1975, the poetics of socialist realism literature has been fading gradually and paving the way for the comeback of mythological poetics. It is clear that revolutionary or politicalised landscapes and chronotopes tend to be replaced by mythological ones. This article analyses the aesthetic characteristics of mythological spaces in contemporary Vietnamese prose illustrated by some works of Pham Thi Hoai, Nguyen Huy Thiep, Ta Duy Anh, and Nguyen Xuan Khanh.

\section{THE BINARY SPACES}

French anthropologist and ethnologist C. Levi-Strauss pointed out the characteristics of primitive man's logical thinking expressed through binaries "commented on the world firstly by the opposing pairs in the most basic of which are two pairs of Gods // Land, and Male // Female (...) From the opposing minds, they found the mediator between them, which has the mission of reconciliation to create balance and harmony. Many rituals, customs, and myths were created to concretize this mediating factor. They [rituals, customs, and myths] are both art and culture as well as concepts and tools to explain the world, that is, they have artistic and religious-philosophical functions" (Trinh, 2011, p. 29). This ethnographer also generalises the triadic principle in which two parts of this triad are in an opposite structure (a dualistic pair), and the remaining part plays an intermediate role in the "resolution of the contradiction." The conclusions of Levi-Strauss have suggested the role and position of myth as an attachable mediation between humans and supernatural forces. The interpretations of Levi-Strauss are proved by interpreting mythological symbols which play "a mediating element": clothing (such as shoes, accessories, etc.) play an intermediary relationship between nature and civilization; a white-collared crow (a kind of scavenger) mediating between herbivores and carnivores; and fog mediating between heaven and earth..." (Trinh, 2011, p. 29).

Following the views of Levi-Strauss, Russian mythological researcher Meletinsky analysed in depth the process of transforming the minds and perceptions of primitive man from myths to fairy tales. He called it "the binary thinking" and "the binary logic of primitive man": "Legendary logic extensively utilizes the binary pairs (a pair) of emotional qualities and simultaneously surmounts "the continuity" of world perception by separating into individual frames with signs of contradiction”(Meletinsky, 2004, p. 219).

Meletinsky's fundamental theories on the binary thinking of primitive man set directions for studying the poetics of mythological chronotopes in ancient myths. At the same time, it suggested exploring the traces and effects of binary thinking in the construction of chronotopes and characters. Binary thinking creates opposites and diversified aesthetics, which are both antagonistic and complementary in a dialectical relationship.

In Nguyen Huy Thiep's mythological works, spatial models were constantly shifted to create events, promote narrative development, and deepen the characters' strategy. These poetics are 
probably influenced by the departure motifs that had a profound root in national myths. The transfer and interchangeability of spaces is a typical characteristic of spatial poetics, especially in ancient myth, as Bakhtin emphasised: "All adventures in the Greek romance are thus governed by an interchangeability of space; what happens in Babylon could just as well happen in Egypt or Byzantium and vice versa. Separate adventures, complete in themselves, are also interchangeable in time, for adventure-time leaves no defining traces and is therefore in essence reversible. Thus, the adventure chronotope is characterised by a technical, abstract connection between space and time, by the reversibility of moments in a temporal sequence, and by their interchangeability in space" (Bakhtin, 2010, p. 100).

In Run River Run, the river was a two-sided symbol: river - death (destruction) and river - life (regeneration); river: mystification and demystification. In Chastity, there is a transformation of space from virtuality to reality and vice versa. It is about the exhumation of Vinh Hoa's grave: "When opening the coffin lid, there is a pink silk layer. Under the layer of pink silk, is a transparent membrane-like jelly, showing up a beautiful woman, a fresh face like a living person..." (Thiep Greg, 1993, p. 158), then the author moved immediately to the actual scene: "After ten minutes, the mist melts all, in the coffin only a black skeleton-like ebony... the coffin was full of dry tea" (Thiep Greg, 1993, p. 158).

In a set of "pseudo-fairy," "pseudo-history" stories, there were two types of contrasting spaces: real and virtual spaces (for instance, The Mother Soul, Run River Run, The Water Nymph, Chastity, A Sharp Sword...). In Run River Run, a character-narrator confessed: "I" is a dream boy with all the illusory desires of the extraordinary and the mythology which are radically opposite to the run-about and gross life in Coc Ferry (Bến Cốc) with too many "murder-robber things," "adulteries" and "gambling"... Besides the realistic details, this story also has magical and mysterious details, such as the skull of a drowned man drifting with his hair full of moss sticking just like ascarids and all his set of teeth sticking with tiny strings. The story about Trùm Thịnh's wonton eating house who uses mouse meat baited arsenic is also imbued with magic nuance: "a bowl of wonton brought to the dog to eat, then dog die. People who eat dog meat also died. After opening a half of month, the old man closed his eating house. Someone told me that when the fire had been being high, a huge rat was running out of the house and laughing".

In The Water Nymph, numerous details are ambiguous between the real or the virtual, such as: "One time, the well-digger Mr. Tu Chung told me about how he had dug up a bronze drum artefact. Officials from the district branch of the Office of Culture visited him and asked to take the drum. But when they started back across the river, the sky suddenly crashed with thunder and lightning, and the wind rose to whip the water into layer upon layer of waves. Mother Cả, who was swimming in the river, yelled: "Throw down the drum." The boat rolled and tossed, almost capsizing, so the officials had no choice but to throw the drum to Mother Cả. She sat on top of the drum and beat out a fast rhythm. And then the thunder quieted, and the rain 
stopped. Mother Cả clasped the drum to her body and dove out of sight to the bottom of the river" (Thiep Greg, 1993, p. 287).

The Mê River Man novel also had a stark contrast between real and virtual spaces. The reality and the illusion intertwined to present the various situations of complicated existential life. The actual space is Hoa's house, the road right beside the school gate where Khanh had an accident, Professor Khoa's office, the dormitory, and the laboratory. Overall, there were symbolic spaces for the disorderly transfer from the subsidisation mechanism to the market one. Interspersed with realistic spaces were magical, fabulous spaces created from the perspectives of dead characters: "I suddenly felt like I was flying to the sky. I was looking down the immense space below and saw a path across the school gate..." (Chau, 2005, p. 17).

In Ta Duy Anh's The Penitent Angel, mythification became a typical technique in recreating a mythic and realistic space. The actual space is described as a sleazy and disgusting maternity hospital, where one person has just been born. Furthermore, in stark contrast to this fearful space is paradise space, where people are "saved and flown onto the heaven by an angel patrolling. Heaven is a place I often desire when I was small...” (Ta, 2004, p. 118).

There is a poetic feature becoming stable and popular in contemporary Vietnamese prose. Mythological writings do not build single-dimensional spaces but rather pluralistic and antagonistic spaces that are irreconcilable. The spatial structure is based on binary models, such as the virtual - the real, the sacred - the profane... By normalising strange things, breaking the gap between the normal and the odd, and simultaneously increasing the frequency of virtuality and legendary, writers convey profound artistic ideas. It can be concluded that the overwhelming presence and dominance of modern and mundane social-cultural codes in contemporary myths.

\section{THE SPIRITUAL AND LEGENDARY SPACES}

Contemporary Vietnamese mythological writings have marked the resurgence of spiritual and magical chronotopes deeply rooted in ancient mythologies or literary genres, such as medieval fantasy and fairy tales. However, as we have emphasised, the appearance and domination of social, cultural, and historical codes and sediments in modern mythological writings, the mythological poetics do not merely combine the myths as a strategy of narrative defamiliarisation but also represent the intricating issues of modern-day life by transforming the ordinary, the intelligible, and the real into the extraordinary, the unintelligible, and the virtual.

Nguyen Xuan Khanh created in The Goddess of the Highlands mythological spaces in harmony with civilian life, festivities, and customs. Naturally, the author regenerates and recontextualises mythological materials, stories, and characters to mould the Mother Goddess Religion's representations. Nguyen Xuan Khanh reproduces myths through the very 
mythological thinking of the primitive man, that is, the description of animism worlds: "Every river, every forest, every inch of soil, has buried the bodies of their ancestors. All of that comes together to create the soul of the earth." (Nguyen, 2012, p. 216). The indigenous peoples' cautions of the powerful and dominating presence of the divine world in this tropical land have casused fascination, inquisitiveness, obsession and fearfulness for foreign civilizers: "In this country, every house worshipped Earth Genie. The soil also has its soul; it is the earth's spirit. It is a synthesis of human souls, ghosts, souls of plants, ponds, and stones (...) They (the autochthonous) worship the mystery and sacred of all nature.” (Nguyen, 2012, p. 93).

Building mythological spaces, Nguyen Xuan Khanh always associated the roots of spiritual culture being inculcated in the national unconsciousness. Fabulous spaces have surrounded the stories of the two brothers Dung - Da, which reminisce about the national legend of Ông Đùng bà Đùng (also Ông Đùng bà Đà). Additionally, the magical details of a pair of basilisks (rắn thần), a couple of horse genii of the Mother Goddess, together with orally transmitted stories, make a substantial contribution to the magic and unique characteristics of mythological spaces. Moreover, Nguyen Xuan Khanh permanently embeds national myths in the mythological spaces.

In the cluster of mythological stories, Nguyen Huy Thiep also attends to construct a kind of space that permeates the mythological nuances. In The Water Nymph, the legend of the birth of Mẹ Cả (Great Mother) is transmitted orally with numerous illusory and strange things: “...the summer storm 1956. It was in that storm, on Nổi ground in Cái River, lightning struck a great and ancient mango tree. I am not sure someone who said that they saw a pair of tightly entwined water monsters thrashing about, muddying the entire stretch of river. When the rain stopped, a newborn infant lay at the foot of a mango tree. The baby is a child of The Water God left" (Thiep Greg, 1993, p. 286). With methods of mythological regeneration, Nguyen Huy Thiep has the sense of "overcoming" the poetics of ancient mythological chronotope by "attaching" implications for specific but ambiguous times and places (for example, in 1956, that summer, a summer storm, Nổi ground, Cái river). This method immerses the story in virtual and real nuances by paralleling and blending strange and mystical elements (such as water monsters and a new baby).

Through the spiritual and mythic elements, writers have expressed the concept of a multidimensional and pluralistic world existing side by side with the binary systems, for instance: virtual - real, solvable - insolvable, rational - irrational, evidently - fortuitous and realistic conceptional.

\section{THE SYMBOLIC SPACES}

In the article "The Literary Myths: The Moment of Light and Transform in Modern Writings," Dang Anh Dao emphasised the presence of metaphors, symbols, and archetypes in Vietnamese literature through mythological techniques. On the one hand, myths are "deeply rooted in 
collective memory" (Dang, n.d.); on the other hand, they show the ability to "illuminate" the eternally existential problems of humanity. For great works, the "repetitive" spatial symbols tend to contain "significant discourses." They are likely to transform into archetypes that are consolidated meanings over time and have universal meanings beyond the boundaries of a nation/culture. Some archetypes, namely earth, water, fire, and forests, are constantly fragmented into symbols. For example, the water archetype varies into its "variants" such as rivers, ponds, lakes, air, steam, dew, breast milk, and even blood...

The symbolic space is the room in The Crystal Messenger, reminisces about room space in Kafka's works. Samsa (The Metamorphosis) who is turned into a giant beetle, must live in his closed room all day until death. In The Trial, stringing obsessions with the closed and stuffy room make Josep K feel like choking: "the air is very stuffy and heavy." Is the "room" a symbol of the stuffy life, the enslavement of thought, or the preposterousness of life? Putting Pham Thi Hoai's The Crystal Messenger in an intertextual and intercultural network with her other compositions (Sunday Menu, Sai Gon Tailor Shop, Sen Maria) or beyond with Kafka's works (The Trial, The Metamorphosis) it is not difficult to recognise this symbolic meaning of the room repeated as a textual cohesion. The room space is characterised by its very closed, dull, dark, and cramped characteristics and represented as a polysemous symbol. With all its cramped, confined, and unlovable characteristics, it is a bitter symbol of the stifling urban life of Hanoi in the last decades of the twentieth century - the period transferred from the subsidisation to market mechanism.

In The Water Nymph, the sea appears 22 times in the daydreams and reflections of Chương. This commodious and dreamy space brings revitalisation, which opposites to spleenful and realistic pastoral spaces engulfing Chương in monotonousness: "I would return to the work of the previous ten years and continue to do it until the end of my days: ploughing in the morning, digging laterite in the afternoon, stripping bamboo in the evening" (Thiep Greg, 1993, p. 302).

Urban and rural symbols perennially appeared as a constant obsession in the stories of Nguyen Huy Thiep. A symbol of modern life in the streets with lavish feasts and ephemeral dreams, but on the other hand, symbolises the tragic degradation of social morality and the absence of humanity. Moreover, the characters of Nguyen Huy Thiep live in a dreamland of rural and mountainous, non-humanly environmental and natural spaces, as opposed to urban space and civilization. Therefore, there have been spatial movements from the city to the countryside, from noisy and nonhuman spaces to tranquil and natural ones. With Hien (Lessons from Countryside), the city is like a phobia and a haunting shadow as "Hanoians all look cruelty" (Thiep Greg, 1993, p. 25). With Tan - Hien's husband, "City people are all scoundrels" (Thiep Greg, 1993, p. 25). The city symbol exists as a pseudo-valuable space full of instability where the evil, the bad, the luxurious, the false, and the frivolous degenerate human qualities (for example, uncle Phung in Remembrance of the Countryside). The journey from the countryside to the city is how human beings became deprived/lost of human qualities. Nguyen Huy Thiep has predicted life city with numerous tricky things, where human beings are corrupted, 
transformed catastrophically and where the forces of money had dominated/overwhelmed all levels of moral values.

It is possible to perceive that the symbolic spaces of rooms, urban and rural areas, on the one hand, are both repetitive spatial symbols, becoming the leading spaces. However, simultaneously, each symbolic space "glows" and "implicates" the metaphorical meanings of human life.

\section{CONCLUSION}

The penetrations of the myths and the dominations of mythological thinking into literary writings are most evident in the transformations of aesthetic images and narrative structures. A fact cannot deny that contemporary Vietnamese literature has witnessed a significant development of mythological writings, particularly in the short story. Some mythological spaces are created to convey artistic ideas through parody, demystification, or revitalisation of mythological motifs and materials. Myths have been continuously regenerated, transformed, adapted, and invaded into the literary domain, creating unique changes in the work's narrative structures and aesthetic images.

\section{AUTHOR'S BIOGRAPHY}

Quoc Hieu Le, is a researcher at Vietnam Institute of Literature (IoL), Vietnam Academy of Social Sciences, Hanoi. His research interest includes Film Studies, Literary Theory, Adaptation, and Masculinity. 
International Journal of Innovation, Creativity and Change. www.ijicc.net

Volume 15, Issue 8, 2021

\section{REFERENCES}

Bakhtin, M. M. (2010). The dialogic imagination: Four essays (Vol. 1). University of texas Press.

Chau, D. (2005). Người sông Mê (The Mê River Man). Vietnam Writer's Association Press.

Dang, A. D. (n.d.). Huyền thoại văn chương: Thời điểm phát sáng và biến hóa trong văn học viết hiện đại (The Literary Legend: The Moment of Light and Transform in Modern Writings). Retrieved November 5, 2021, from https://lythuyetvanhoc.wordpress.com

Le, Q. H. (2017). Khuynh hướng giải huyền thoại trong văn xuôi Việt Nam đương đại từ 1986 đến nay (The Tendency of Demystification in Vietnamese Contemporary Prose from 1986 to Present). Song Huong, 342, 42-53.

Meletinsky, E. M. (2004). Thi pháp huyền thoại (The Poetics of Myth). Hanoi National University Publishing House.

Nguyen, X. K. (2012). Mẫu Thuợng Ngàn (The Goddess of the Highlands). Women's Publishing House.

Ta, D. A. (2004). Thiên thần nổi giận (The Penitent Angel). Vietnam Writer's Association Press.

Tamarchenko N. D. (2015). CHRONOTOPE. In LÃ NGUYÊN -La Nguyen. https://languyensp.wordpress.com/2015/02/09/chronotope/

Thiep Greg, N. H. A.-L. (1993). The General Retires and Other Stories. Oxford University Press. https://www.amazon.com/General-Retires-Other-Stories/dp/0195885805

Trinh, B. D. (2011). Structuralism in Literature. Vietnam Writer's Associate Press. 